\title{
Analysis of Re-purchase Intention by Hybrid Rice Seed Farmers
}

\author{
Soesilo Hadimartono* \\ Magister Manajement and \\ Business, School of Business \\ Bogor Agricultural University
}

\author{
Ujang Sumarwan \\ Magister Manajement and \\ Business, School of Business \\ Bogor Agricultural University
}

\author{
Bunasor Sanim \\ Magister Manajement and \\ Business, School of Business \\ Bogor Agricultural University
}

*Corresponding author: soesilo.hadimartono@gmail.com

\begin{abstract}
Rice demand will continue to increase along with the project rate of population increase. The use of quality seed was the thing to get attention. Therefore, it is necessary to analyze the factors that affect the interest in the purchase of hybrid rice seeds by farmers. The analysis showed that the factors affecting the purchase of hybrid rice seed is the attitude, subjective norm and perceived behavior control. Perceived behavioral control or perceived behavior control according to respondents, it is a factor that determines the first to affect the level of the purchase of hybrid rice seeds. A further factor affecting is subjective norm then the last one is the attitude. Purchase behavior of hybrid rice by farmers in the marketing area Region I Sukamandi PT Sang Hyang Seri is influenced by the contact farmer who can be contacted, the suggestion of extension local hybrid rice, and the influence of most small marketing is done by PT Sang Hyang Seri itself. Variables influence the perception of control behavior which is in contrary to existing theories. The analysis showed a negative influence, that is, it is possible for farmers who are in the hybrid rice production center. In addition, the general marketing of rice farmers in the region Region I Sukamandi PT Sang Hyang Seri using rice seeds last in 2014, in which time was the existence of government subsidies that encourage farmers to use hybrid seeds in order to increase national rice production.
\end{abstract}

Keywords: hybrid rice, purchase intention, multiple regression

\begin{abstract}
Abstrak. Kebutuhan padi akan terus meningkat seiring dengan proyeksi laju pertambahan penduduk. Penggunaan benih bermutu merupakan hal yang perlu mendapat perhatian. Oleh karena itu, diperlukan adanya analisis faktor-faktor yang mempengaruhi minat pembelian ulang benih padi hibrida oleh petani. Faktor-faktor yang mempengaruhi minat pembelian ulang benih padi hibrida terdiri dari Attitude, Subjective norm, dan Perceived behavior control. Perceived behavior control atau persepsi kontrol perilaku menurut responden merupakan faktor yang menjadi penentu pertama yang mempengaruhi tingkat pembelian benih padi hibrida. Faktor selanjutnya yang mempengaruhi adalah Subjective norm atau norma subyektif kemudian yang terakhir adalah attitude. Perilaku pembelian padi hibrida oleh petani di wilayah pemasaran Regional I Sukamandi PT Sang Hyang Seri (Persero) dipengaruhi oleh kontak tani yang dapat dihubungi, anjuran dari penyuluh setempat untuk menggunakan benih padi hibrida, dan pengaruh paling kecil adalah pemasaran yang dilakukan oleh PT Sang Hyang Seri (Persero) itu sendiri. Pengaruh variabel persepsi kontrol perilaku bertolak belakang dengan teori yang ada. Hasil analisis menunjukkan pengaruh yang negatif. Hal ini, dimungkinkan karena petani hibrida yang berada pada sentra padi. Selain itu, secara umum petani padi di wilayah pemasaran Regional I Sukamandi PT Sang Hyang Seri (Persero) menggunakan benih padi terakhir pada tahun 2014, dimana pada saat itu adanya subsidi dari pemerintah yang menganjurkan petani menggunakan benih padi hibrida agar produksi padi nasional meningkat.
\end{abstract}

Keywords: beras hibrida, minat pembelian, regresi berganda 


\section{Introduction}

Rice (Oryza sativa) is one of the staple food for the Indonesian people. Since Indonesia's independence, the Indonesian government have the appreciation from FAO which is to achieve rice self-sufficiency. It happened in 1984, then again in 2008. Seeing the reality of what happened, rice became a fundamental and strategic commodities so that rice management requires special attention from the government and other stakeholders.

The use of quality seed is the thing to get attention, commodity of rice, palawija, as well as horticulture. The success of the three is determined by the quality of seeds used. Other inputs such as fertilizers and pesticides will provide positive support when farmers use quality seed. Quality seed encompasses three things which are inseparable, that is, physical quality, physiological quality and genetic quality (Sadjad, 1993). Among the variety of high-yielding rice seeds, in this last period, hybrid rice is the one that gets the attention of the government. Data of Directorate General of Food Crops, since 2001 until now show that the number of hybrid rice varieties have been released as many as 98 varieties, consisting of 23 varieties of domestic results, and 75 varieties are the result from the introduction of the outside. Growing varieties now include HIPA 8, SL 8, SHS, Sembada 168, Sembada B 09, Mapan P05, Candra, H6444 and PP3 (IAARD 2007).

Hybrid rice varieties have excellences compared to open pollinated varieties of rice seed (inbred), which contributed greatly better in the increased production, vigor, physiological and morphological aspects (Virmani and Khumar 2004). If we compare the productivity between hybrids and inbreds, it is seen that the hybrid seeds will be able to increase production up to 8-11 tons per hectar compared with inbred rice that produces 7-8 tons per hectars for locations in Java (Satoto and Suprihatno 2008).

In fact, the quality of hybrid seeds can't replace the use of inbred seed, data from the Directorate General of Food Crops in 2015 showed that in 2015 the area allocation of hybrid rice which has been used in Indonesia was 50.000 hectares, while 300.000 hectares are allocated to the region inbred rice (regular rice) from natural seeds that obtained from the farmers themselves with a technique that are still simple.

According to Zaini (2008) and Wahyuningsih (2009) there are some things that constrain the development of hybrid rice seeds with the variety that was released largely as the result of production from abroad which had different character of varieties with the environment in Indonesia, so frequently breakdowns in production hybrid rice seed or it's required more time to adapt. Another obstacle that keeps the farmers prefer to plant rice seeds of inbred than hybrid is the price of seeds is relatively expensive. Hybrid rice price in the range of IDR 70.000 per $\mathrm{kg}$, rice seed was only IDR 10.000 per kilogram with a seed needs about $15-20 \mathrm{~kg}$ per hectare.

To increase the use of hybrid rice seeds, the marketing team of PT.Sang Hyang Seri needs to learn what the background of the farmers is in the decision to use hybrid rice seeds. Attitudes are the important factors that will influence the decision of consumers (farmers). Theory of Planned Behavior (TPB) is a model that estimates the attitude of consumer interest or intention to perform a behavior 
or action (Sumarwan 2011). The intention is not only dependent on the attitude, but also the norms of subjective or social pressure that is done by others, such as farmer contacts or friends, to perform or not perform a behavior (Haryono 2013). According to Peterson (2012), intention is an important predictors of behavior, in which the intention is determined by the attitude toward the behavior to be performed, norms subjectively (subjective norms) which relates to the behavior to be performed, and control the behavior (perceived behavioral control) to perform the behavior. Wiethoff (2004) proposed a draft training model based on the Theory of Planned Behavior. He tried to apply the Theory of Planned Behavior to influence the motivation to learn in the Diversity Training Program. He chose to discuss diversity training program because he saw the importance of the training program.

Regional I Sukamandi PT.Sang Hyang Seri is as one of government providers of hybrid rice seeds in Indonesia. In the current competitive situation, it must be able to utilize its resources to increase the added value of a product before it is delivered or sent to the customer. Increasing the value-added products is intended that the First Regional Sukamandi PT.Sang Hyang Seri can improve its competitiveness in hybrid rice seed industry in Indonesia.

Currently, marketing conditions faced by First Regional Sukamandi PT Sang Hyang Seri tends to decrease the number of hybrid seeds sold continued to decline since 2012 of $424.185 \mathrm{~kg}$ to $116.375 \mathrm{~kg}$ in $2013,157.627 \mathrm{~kg}$ in 2014 , and the lowest was 15.850 on 2015, and of course this will greatly affect the company's performance by taking into account the yield from the sale of hybrid seeds, which is also declining.

Regional I Sukamandi of PT.Sang Hyang Seri has four branches, that are in the area Sukamandi, Serang, Ciamis and West Kalimantan. Of the four branch offices, Sukamandi is the largest branch office owned by First Regional Sukamandi PT.Sang Hyang Seri, and in line with the company's sales growth, branch offices Sukamandi has also declined since 2013. It is exciting for researchers to find out how interest rice farmers to re-purchase of hybrid rice seeds, the factors that affect the interests of rice farmers to re-purchase of hybrid rice seeds, and what marketing strategies that should be applied by PT.Sang Hyang Seri that has increased sales of hybrid rice seeds. The purpose of this study was to: (1) analyze the interests of rice farmers to re-purchase of hybrid rice seed, and (2) analyze the factors which affect the interests of farmers.

\section{Method}

Research was conducted at the Regional I Sukamandi PT Sang Hyang Seri. Data used in this study were primary and secondary data, that is, qualitative (descriptive) and quantitative data. Primary data were required with conducted interviews by charging a list of questions to respondent who have and or use of hybrid rice seeds. The population of hybrid rice farmers are based on data from the coordinator of Extension Agents in Subang Regency, West Java. while secondary data obtained from the literature contained in books, research reports, journals, internet, and so is the data supporting or complementary to the primary data. The data were obtained through relevant department agencies such as the 
Central Bureau of Statistics, the Ministry of Agriculture and local government agencies.

Technique of respondents sampling used was convenience sampling. Respondents were selected based on availability and ease to get it (be in place and the right time) and meets a predetermined (Cournoyer and Klein, 2000). Precondition that used in this study are rice farmers who never or hybrid rice. Terms of respondent selection is done with the consideration that the information obtained came from respondents who have and or use of hybrid rice seeds to reduce bias research results.

Data collection was done through questionnaires with explanation to the respondent before filling out the questionnaire. This questionnaire uses Likert scale with a range of grades 1-5. Point 1 is a statement strongly disagree (SD) and point 5 is strongly agree (SA).

The population in this study were all farmers located in the PT Sang Hyang Seri Sukamandi region. The number of farmers is 3.512 people and sample selection is done by using a random sampling using the formula Slovin (Umar, 2003) are:

$$
\begin{aligned}
& n=\frac{N}{1+N \cdot e^{2}} \\
& \text { where: } \mathrm{n}=\text { Sample Size } \\
& \mathrm{N}=\text { Population size } \\
& \mathrm{e}=\text { Percentage }(\%) \text {, tolerance inaccuracy due to sampling error. }
\end{aligned}
$$

Based on the formula Slovin, the number of samples taken in this study are:

$$
\begin{aligned}
& \mathrm{n}=\frac{5217}{1+5217(9 \%)^{2}} \\
& \mathrm{n}=\frac{5217}{43,25}=120,62 \approx 120 \text { respondent }
\end{aligned}
$$

Qualitative data analysis is a form of analysis based on the data expressed in narrative form. Qualitative data is data measured directly (Hadi 2001). Activity of analyze the data in this study include the process of editing, coding, scoring, and tabulation.

Data processing is done by using a scoring technique to describe the perception of respondents to the questions posed. The scoring technique performed in this study is a minimum of 1 and a maximum of 5, then the calculation of the index of respondents performed with the following formula:

Index value $=\{(\% \mathrm{~F} 1 \times 1)+(\% \mathrm{~F} 2 \times 2)+(\% \mathrm{~F} 3 \times 3)+(\% \mathrm{~F} 4 \times 4)+(\% \mathrm{~F} 5 \times 5) / 5$ 
Information:

$\mathrm{F} 1$ is the frequency of respondents who answered 1

F2 is the frequency of respondents who answered 2

$\mathrm{F} 3$ is the frequency of respondents who answered 3

F4 is the frequency of respondents who answered 4

F5 is the frequency of respondents who answered 5

Regression analysis is an analytical tool that measures the effect of independent variables on the dependent variable. Regression types used are multiple regression (Sunyoto 2008). Three aspects are seen and used as a condition of use of regression models that multicolinearity, the coefficient of determination $\left(\mathrm{R}^{2}\right)$, and numbers of significance (t-test and F). Simamora (2004), Wang and Wong (2004) revealed that the direct effect of an independent variable on the dependent variable traced by regression analysis. Regression analysis is a powerful and flexible procedure in analyzing the associative relationship between the independent variable (X) and the dependent variable (Y). Rangkuti (2003) explains that how big the influence of independent variables on the dependent variables, can be measured by the value of the coefficient of determination $\left(\mathrm{R}^{2}\right)$.

The variables that will be examined in this study are:

1. Variable attitude toward behavior (X1) -> influenced by aspects of belief to behavior (bi) and evaluation aspects of consequence (ei).

2. Variable subjective norm (X2) -> influenced by aspects of normative beliefs (ni) and comply with the motivational aspects (mi).

3. Variable behavior control (X3) -> influenced by aspects of control beliefs (ci) and aspects of the power factor control (pi).

\section{Characteristic of Respondent}

\section{Result And Discussion}

The majority of respondents were in the age range above 50 years is as much as 57.5 percent. As for the age under the category of 30 years of only 1.7 percent. 30-39 years old as much as 17.5 percent. In the 40-49 years age category there is 23.3 percent. All respondents rice farmers have been married. The majority of respondents aged couple of farmers were in the age range of 50 years is as much as 49.2 percent. As for the age category under 30 years of only 2.5 percent. 30-39 years old as much as 24.2 percent. In the age category of 40-49 years of age are 24.2 persen.Berdasarkan structure and married status as above, it can be said that respondents rice farmers in Region I Sukamandi PT Sang Hyang Seri is generally dominated by the population in the age range of 50 years, It shows that the interest of young business workers on rice farming is still very minimal.

Based on gender, the respondent has a composition of 95 percent of men and 5 percent of women. Based on the distribution of the gender, it can be said that a group of farmers in Region I Sukamandi PT Sang Hyang Seri is generally dominated by the population with the male gender. The education level of respondents based on the results of the questionnaire showed that most of the graduates of Elementary School, but there are a few of the respondents are graduates of Junior High School and Senior High School. The number of 
respondents as a whole where the biggest education level is as much as 64.2 percent of Elementary School graduates, Junior High School as much as 21.7 percent, 12.5 percent of Senior High School, and education above the Senior High School as much as 1.7 percent. In addition to interest young workforce to the agricultural sector is still relatively low education level of rice farmers is low because the majority of farmers only basic education.

Characteristics of farm that run by the respondents in general is a major effort to earn revenue. Based on the survey results show that 75.8 percent stated that farming is a business that is primary businnes and 24.2 percent stated that dijalankkan farming is a sideline. Based on the structure of gender, education level and and farming that running, it can be said that respondents rice farmers in Region I Sukamandi PT Sang Hyang Seri is generally dominated by men with education is very low (primary school graduates) yet run farm is a major effort. It shows that interest in running a rice farming is still very high.

\section{Farm Activiy}

Acreage farmer respondents were generally less than $2.500 \mathrm{~m}^{2}$. From the analysis of respondents who manage agricultural land less than $2.500 \mathrm{~m}^{2}$ reached 66.7 percent, then the farmer respondents with a land area of $2.500-4.999 \mathrm{~m}^{2}$ reached 22.5 percent, of respondents with agricultural land area of 5.000-7.499 $\mathrm{m}^{2}$ as much as 6.7 percent, and the land area $1.500-9.999 \mathrm{~m} 2$ as much as 1.7 percent, as well as farmers with land area of more than 1 hectare managed as much as 2.5 percent. The results of the analysis of the respondents indicate that most farmers manage the land is still relatively low, below 0.5 hectare.

Respondents generally involve labor in the family to help its business activities as additional labor. From the analysis of the majority of respondents involved one family workers and as many as 50 percent of respondents. Families involved in general is a partner. Then respondents were involved two family members as much as 33 percent, of respondents involving three family members as much as 11 percent, and respondents involving four or more family members as much as 8 percent.

The area of land under cultivation, the status of ownership of land and labor, it can be said that respondents in Region I Sukamandi PT Sang Hyang Seri is generally cultivated land is very small ( $<0: 25$ ha), own property and engage partner as additional manpower. It became evident that many farmers with very small land holdings in Indonesia are under 0.25 ha.

\section{Factors Affecting the Purchase of Hybrid Seed PT Sang Hyang Seri}

Factors that affect the purchase of hybrid rice seeds in PT.Sang Hyang Seri is a decisive factor in determining the success of marketing of hybrid seeds to consumers. Perceived behavioral control according to respondents is a factor that determines the first affecting the level of purchase hybrid seeds. A further factor affecting is subjective norm then the last one is the attitude. Factors affecting the level of purchase of hybrid seeds can be seen in Table 1

Table 1 Average factors affecting the level of purchase hybrid seeds

\begin{tabular}{llc}
\hline No & Determinants rate of purchase & The average Opinion \\
\hline 1 & Attitude toward behavior & 3.65 \\
\hline
\end{tabular}




\begin{tabular}{lll}
\hline 2 & Subjective norm & 3.93 \\
3 & Perceived behavior control & 4.39 \\
\hline
\end{tabular}

Note: 1 = strongly disagree, 5 = strongly agree

\section{Attitude}

Attitude is something that describes what you liked and disliked and lead to action to accept or reject anything. In terms of determining the marketing strategy of hybrid seeds PT Sang Hyang Seri, which affects the attitude there are 2 kinds, namely belief in the behavior (behavior belief) and variable evaluation of the consequences (outcome evaluation).

Respondents expressed the belief of the hybrid rice will benefit from increased production, making it harvesting fast and make a lot of rice tillers.

\section{Subjective Norm}

Subjective norm is defined as personal perceptions about the beliefs of others, which the trust the people closest to affect its behavior to do and not do something. In terms of determining the marketing strategy of hybrid seeds PT Sang Hyang Seri, there are two kinds of subjective norm, ie normative beliefs and motivation of comply. Respondents agree to follow the advice of contact farmer or farmer group chairman, Agricultural Extension Workers and Sales Force PT.Sang Hyang Seri for the use of hybrid rice seeds.

\section{Perceived Behavior Control}

Perceived behavioral control is the ease or difficulty for someone to be able to perform the behavior. In terms of determining the marketing strategy of hybrid seeds PT.Sang Hyang Seri, perceived behavior control there are two kinds, namely the control belief and the power of factor control.

Respondents agreed purchase of hybrid rice seeds if can be sold and delivered directly, the price of hybrid rice seeds no more than five times that of rice seed always, is available at a retail store means of agricultural production close to home and conviction productivity of hybrid rice seed is higher than seed regular rice.

\section{Re-purchase Intention of The Hybrid Seed by Farmers}

Wijaya (2008) revealed that the intention was formed through a process in which the trust decision concerning subjective norms and attitudes toward behavior are considered and integrated in order to evaluate the behavior. The components that make up the behavior intention in this study is the attitude toward the behavior, subjective norms, and perceived behavioral control.

The results support the theory of reasoned action of Ajzen and Fishbein stating that the intention is strongly influenced by the attitude and subjective norm. This study is also in accordance with previous studies conducted by Taib, Ramayah, Razak (2008) which states that the attitude variable and subjective norms have a significant effect on the intention to use Islamic banking products. The study also supports research Dunn et al. (2001), Downs (2006), and Dominanto (2008) who found that the attitude positive and significant in explaining purchase intentions. This study is also consistent with research 
Mukodim (2007), Marhaini (2008), and a Bellman who concluded that subjective norms significantly influence purchase intention.

Table 2 describes the components forming the interest in the purchase of hybrid seeds by farmers who have been produced by PT. Sang Hyang Seri. Question 1 in Table 2 for components of attitudes toward the behavior is an indicator that the use of hybrid rice seeds profitable with a score of 19.19 (high), question 2 that the hybrid rice seeds make a quick harvest time with a score of 6.80 (high) and question 3 that seed hybrid rice paddy saplings makes a lot with a score of 11.59 (high). Based on these results, the sequence indicator of attitudes toward the behavior contribute to shaping the intention is to provide the advantages of increased production, making many rice tillers and make harvesting faster. Meanwhile, questions 1 in Table 2 for components of subjective norms are indicators that recommended by farmer groups score of 17.26 (high), the second question or suggestion Agricultural Extension Workers (AEW) score of 8.99 (high) and question 3 instigation sales force PT SHS with a score of 13.58 (high). Therefore, the order of the indicators of subjective norm is a suggestion farmer groups, marketing personnel PT SHS and AEW.

Table 2 Component-forming behavior

\begin{tabular}{|c|c|c|c|c|c|c|c|c|c|}
\hline \multirow[t]{2}{*}{$\mathrm{P}$} & \multicolumn{3}{|c|}{$\begin{array}{l}\text { Attitude toward behavior } \\
\text { (Aact) }\end{array}$} & \multicolumn{3}{|c|}{ Subyective Norm (SN) } & \multicolumn{3}{|c|}{$\begin{array}{l}\text { Perceived Behavior } \\
\text { Control (PBC) }\end{array}$} \\
\hline & bi & $\mathrm{Ei}$ & bi $x$ ei & $\mathrm{Ri}$ & $\mathrm{mi}$ & ri $\times \mathrm{mi}$ & pi & $\mathrm{Ci}$ & pi $x$ ci \\
\hline 1 & 4.23 & 4.53 & 19.19 & 4.18 & 4.13 & 17.26 & 4.4 & 4.54 & 19.98 \\
\hline 2 & 2.18 & 3.13 & 6.80 & 3.98 & 2.26 & 8.99 & 4.13 & 4.07 & 16.81 \\
\hline 3 & 3.98 & 2.92 & 11.59 & 3.63 & 3.74 & 13.58 & 4.52 & 4.56 & 20.61 \\
\hline Mean & & & 4.18 & & & 4.43 & & & 6.38 \\
\hline Category & & & High & & & High & & & High \\
\hline
\end{tabular}

Question 1 in Table 2 for the control components of behavior are indicators delivered directly by a score of 19.98 (high), question 2 indicator price is not more than five times the ordinary rice seed with a score of 16.81 (high) and question 3 indicators available in stores nearest retailer with a score of 20.61 (high). Therefore, the order of the indicators of control behavior in contributing to forming intentions, which are available at a nearby retail store, hand, and the price is not more than five times the ordinary rice seeds.

\section{Factors choosing behavior of hybrid seeds PT Sang Hyang Seri}

Results of processing by seeing the influence of the independent variables, namely X1 (Attitude), X2 (Subjective norm), and X3 (Perceived behavioral control), the dependent variable is Y (Actual Purchase) can be seen in Table 3. The regression equation of this research are:

$$
Y=1.569+0.389 X_{1}+0.898 X_{2}-0.724 X_{3}
$$

The results of calculations using $\alpha=5 \%$ indicates that all independent variables significantly influence the dependent variable. The independent variable 
overall give effect of $30.3 \%$ (coefficient of determination or $\mathrm{R}^{2}$ ) to dependent variable, so that $69.7 \%$ of change in the dependent variable is determined by numerous factors outside factors are categorized as independent variables in this study.

Based on the analysis of variance, then the overall model can be considered as a good model to explain the relationship between the independent variable and the dependent variable ( $F=16830$ with $\alpha=5 \%$ ). The results of this analysis indicate some elements behind the purchase of rice seed at the farm level have a significant influence on the actual purchase (actual purchase) hybrid seeds are the result of PT Sang Hyang Seri . Factors beyond the independent variable in this research is to give effect to the purchase Current hybrid rice seed PT Sang Hyang Seri at the farm level.

Tabel 3 Analyze of Factor Purchase Hybrid Rice Seed PT Sang Hyang Seri

\begin{tabular}{|c|c|c|c|c|c|c|c|c|}
\hline \multirow{2}{*}{\multicolumn{2}{|c|}{ Model }} & \multicolumn{2}{|c|}{$\begin{array}{l}\text { Unstandardized } \\
\text { Coefficients }\end{array}$} & \multirow{2}{*}{$\begin{array}{r}\text { Standardized } \\
\text { Coefficients } \\
\text { Beta }\end{array}$} & \multirow[b]{2}{*}{$\mathrm{T}$} & \multirow{3}{*}{$\begin{array}{l}\text { Sig. } \\
.054\end{array}$} & \multicolumn{2}{|c|}{ Collinearity Statistics } \\
\hline & & \multicolumn{2}{|c|}{ B Std. Error } & & & & Tolerance & VIF \\
\hline 1 & (Constant) & 1.569 & .807 & & 1.944 & & & \\
\hline & $\mathrm{X}_{1}$ & .389 & .141 & .243 & 2.757 & .007 & .772 & 1.295 \\
\hline & $\mathrm{X}_{2}$ & .898 & .186 & .442 & 4.834 & .000 & .720 & 1.389 \\
\hline & $\mathrm{X}_{3}$ & -.724 & .172 & -.360 & -4.216 & .000 & .825 & 1.212 \\
\hline
\end{tabular}

a. Dependent Variable: Y

Attitude of the hybrid seeds of PT Sang Hyang Seri is determined by the gains if the hybrid rice, hybrid seeds to increase production, and accelerate harvesting. This variable obtained a coefficient of 0.389 ; can be interpreted if the attitude of farmers to accept the hybrid rice increased by one unit, the actual purchase of hybrid rice PT Sang Hyang Seri will be increased by 0389 units, assumed the other variables held constant. Attitude variable give positive and significant impact on the actual purchase of hybrid seeds in PT Sang Hyang Seri where the value of $\operatorname{sig}<0.05(\alpha=5 \%)$. In this case farmers have confidence that the use of hybrid rice gives the impact of increased profits from production, harvest time will be faster, and will produce chicks more so that such beliefs can improve farmer behavior in intensity purchase of hybrid rice seeds in the hopes of farmers earn higher profits. Beliefs or attitudes believe in the background of this hybrid seed growers generally experience ranging from 1-10 years. Farming experience can illustrate the use of hybrid seeds compared with inbred rice.

Subjective norm variable have coefficients amounted to 0.898; can be interpreted if it influences of people's beliefs (subjective norm) increased by one unit will increase the actual purchase as much as 0.898 units of hybrid rice PT Sang Hyang Seri, assumed other variables remain. Subjective norms variable give positive and significant impact on the actual purchase hybrid seeds PT Sang Hyang Seri where the value of $\operatorname{sig}<0.05(\alpha=5 \%)$. Farmers with the majority of elementary education and the scale of farming is still relatively small at ranges of less than $2.500 \mathrm{~m}^{2}$ are generally incorporated in a farmer group. This is what gives the group confidence trends by reference in selecting rice seeds to be used. 
The purchasing behavior of hybrid rice by farmers in the marketing area of PT Sang Hyang Seri Regional I Sukamandi influenced by contact farmer who can be contacted, the suggestion of extension local hybrid rice, and the influence of most small marketing is done by PT Sang Hyang Seri itself. Reference group which affect the purchase of hybrid rice seeds can be used as consideration for PT Sang Hyang Seri in planning appropriate marketing strategy to increase sales of hybrid seeds produced.

Perception of control behavior is the ease or difficulty for someone to be able to perform the behavior. This variable have coefficients -0.724 ; can be interpreted if the consumer perception of the ease or difficulty for someone to obtain hybrid seed increased by one unit will lower the actual purchase of hybrid rice PT Sang Hyang Seri amounted to 0.724 units, assuming other variables remain. Perception of control variables influence the behavior contrary to existing theories, in which perceptions of behavioral control should be a positive influence on the purchasing behavior of hybrid seeds PT Sang Hyang Seri . The analysis showed a negative influence. It is possible for farmers who are in the hybrid rice production center. Moreover, it is generally rice farmers in the marketing of PT Sang Hyang Seri Regional I Sukamandi using the last rice in 2014, at which time the existence of government subsidies that encourage farmers to use hybrid rice in order to increase national rice production. The program does not exist then the farmers have a tendency not to use the rice. In addition, of the characteristics of existing farmers dominated earn income outside the farming greatest. This suggests that rice farmers activity being run only as a sideline in meeting their needs.

Theory of Planned Behavior state that a person can act on the intention or the intention is formed of attitude toward behavior, subjective norms, and perceived behavioral control of the individual to a behavior. In theory, these three factors have a positive influence on the purchasing intentions of hybrid seeds PT. Sang Hyang Seri . In this study it was found that perceived behavior control have a negative impact on purchase intentions hybrid seeds. Compared with previous studies conducted by Kolvereid where research supports the Theory of Planned Behavior. The results showed that the independent variables attitude, subjective norm and PBC with the intentions as dependent variables contributed significantly to the explanation of the variation of intentions.

The research related to the purchase intention done by Yacoub (2012) explains that the PBC will affect purchase intentions but it would be different if the consumer has a different level of subjective knowledge about the research on the influence product.Related to the PBC to the purchase intention of hybrid rice seeds of PT.Sang Hyang Seri in this study that give the negative impact of this is due to the marketing of hybrid seeds PT.Sang Hyang Seri is not focused on Subang Regional, place where the study was conducted.

\section{Conclusion}

\section{Conclusion and Recommendation}

Based on the analysis performed, it can be concluded that the factors influencing the purchasing behavior of hybrid rice seeds on farmers in Region I Sukamandi PT.Sang Hyang Seri (Persero) is influenced by the perceived behavior 
control farmers, that is the availability of hybrid rice seed in the retail store that close to home and have cost no more than five times higher than inbred rice seeds.

In addition, the attitude toward the behavior, subjective norm, and control the behavior give significant influence in the purchase of hybrid rice seeds by farmers. Attitude (attitude) of farmers on hybrid rice seeds from PT Sang Hyang Seri (Persero) increases because farmers have confidence gains if the hybrid rice, can increase production, and accelerate harvesting.

\section{Recommendation}

This study they used convenience sampling sampling techniques. In a subsequent study can using purposive sampling technique, it is hoped that the selected sample can be used to estimate population characteristics more objectively.

Some things that can be delivered as advice is just take the example of research in Subang district, the region is expected next study sampled more widely, thus representing a population of users of hybrid rice seeds.

Subsequent research in order to add other factors that have not been examined in this study, such as the perceived of usefulness, perceived ease of use, etcetera. Thus would strengthen the concept to study the factors that affect the interest to buy hybrid rice seeds.

\section{Reference}

Ajzen, I. 1988. Theory of Planned Behavior and human decision process. Journal Marketing Research 50 (2): 179-211.

Ajzen, I., Driver, B.L. (1990). Application of Theory of Planned Behavior to Leisure Choice, Proceedings sixth Canadian congress on leisure research.

Ajzen, I. (2005). Constructing a TPB Questionaire: Conceptual and Methodological Consideration. Ohio.

Bellman, Lawrence, M. (2009). Fashion Accessory Buying Intentions Among Female Millennials. Review of Business; 30(1): 46-57

Cooper, D., Emory, W. (1997). Business Research Methods (translation). Erlangga Volume 1. Jakarta

Cournoyer, David E. dan Waldo C. Klein. 2000. Research Methods for Social Work. Allyn and Bacon, USA

Dharmmesta, B.S. (2003). The strategic decisions to explore consumer attitudes and behavior. Journal of Economics and Business Indonesia. 12 (3): 1-19.

Dominanto, N.N. (2008). Differences in Attitudes toward Advertising, Brand and Consumer Intentions Buy Ads Appeal to Fear High and Low on Women participants. Journal of Economics and Business 2 (2): 67-75

Downs, D.S. et al. (2006). Youth exercise intention and past exercise behavior: examining the moderating influences of sex and meeting exercise recommendations. Journal American Alliance for Health, Physical Education, Recreation and Dance, 77 (1) : 91-99.

Dunn, M.S. et al. (2001). The Influence of significant others on attitudes, subjective norms and intentions regarding dietary ssupplement use among adolescent athletes. Journal Management Vol.36 (143): 583-591 
Fishbein, M., Ajzen, I. (1975). Belief, Attitude, Intention, and Behavior: An Introduction to theory and Research. Ed ke-3. Massachusetts (UK): Addison Wesley Reading MA.

Ghozali, I. (2006). Structural Equation Modeling : Alternative Method with Partial Least Square ke - 2. Universitas Diponegoro Publlisher Agency : Semarang.

Jogiyanto, H. (2007). The success of the information technology system model. Andi Press. Yogyakarta (ID)

Mandasari, N. (2013). The influence of consumer attitudes and subjective norm on purchase intention of Toyota Agya in Denpasar. Udayana University of Management Journal, Vol 2 (11): 1434-1448.

Marhaini. (2008). Analysis of consumer behavior in purchasing brand acer computer (Case Study: Students of Faculty of Economics, University of North Sumatra). Journal of Business Management, 1 (3): 89-96

Mukodim, Didier, Erliansyah. (2007). Variables that affecting consumer decision in buying products cell phones. Journal of Business Economics 12 (3), pp: 220-229

Munandar. (2014). Influence of attitudes and subjective norms on use intentions of islamic banking products at Bank Syariah Aceh in Lhokseumawe. Visionary and Strategic Journal, Vol.3 No.2, hal.73-80

Rangkuti, F. (1999). SWOT Analysis: Dissecting Techniques of Business Case. PT Gramedia Utama Pustakatama. Jakarta.

Sadjad, S. (1993). From seed to seed. PT. Gramedia Widiasarana Indonesia. Jakarta.

Satoto, Suprihatno, B. (2008). Development of hybrid rice in Indonesia. Journal of the Science of food crops Vol 3 (1): 27-40

Siahaan, B. (2015). Factors that influence of use intention local soy sauce. Family \& Consumer Science Journal, Vol. 8 (2): 125-132.

Sumarwan, U. (2004). Consumer Behavior: Theory and Application in Marketing. Ghalia Indonesia. Jakarta

Taib, Ramayah, Razak, T. (2008). Factors influencing intention to use diminishing partnership home financing. International Jurnal Of Islamic And Middle Eastern Finance And Management. Vol.1(3): 235-248.

Virmani, S.S., Khumar, I. (2004). Development and Use of Hybrid Rice

Wahyuningsih, S. (2009). The role of medium small business in the economy of Indonesia. Mediagro Journal, 9 (1): 1-14.

Wang, C. K, Wong, P. K. (2004). Entrepreneurial interst of university student in Singapore. Journal Technovation, 24: 163-172.

Wiethoff, C. (2004). Motivation to learn and diversity training: Application of the theory of planned behavior. Human Resource Development Quarterly, 15(3), 263-278.

Yacoub, Y. (2012). Effects of unemployment on poverty districts/cities in West Kalimantan Province. Journal of the Faculty of Economics, University Eksos Tanjongpura, 8 (3): 176-185.

Zaini, A, Erythrina. (2008). Development of hybrid rice with TT approach and rice markers. Journal of the Science of Food Crops 3 (2): 156-166. 